\title{
ISLAMIC STOCK MARKET AND SUKUK MARKET DEVELOPMENT, ECONOMIC GROWTH, AND TRADE OPENNESS (THE CASE OF INDONESIA AND MALAYSIA)
}

\author{
Harjum MUHARAM ${ }^{1}{ }^{\mathbb{D}}$, Resi Junita ANWAR ${ }^{2}$, Robiyanto ROBIYANTO $^{3}$ \\ ${ }^{1,2}$ Faculty of Economics and Business, Universitas Diponegoro, Semarang 50241, Central Java, Indonesia \\ ${ }^{3}$ Faculty of Economics and Business, Satya Wacana Christian University, Salatiga 50711, Central Java, Indonesia \\ E-mails: ${ }^{1}$ hardjum@gmail.com (corresponding author); ${ }^{2}$ bsbud2013@gmail.com; ${ }^{3}$ robiyanto@staff.uksw.edu
}

Received 21 January 2019; accepted 26 March 2019

\begin{abstract}
This study was conducted in order to analyse the two-way relationship between the Islamic stock market and sukuk market development, and economic growth. this study also analyses whether trade openness influences the development of the Islamic stock market and sukuk market, and economic growth. VAR (Vector Auto Regressive), VECM (Vector Error Correction Model), and a Granger Causality Test used to test the hypothesis. Using Indonesia and Malaysia as the sample countries and from February 2008 to December 2017 period, the results showed that there is a bi-directional causality between the development of the Islamic stock market and the development of the sukuk market in Indonesia and Malaysia. There is a bi-directional causality between the development of the Islamic stock market and sukuk market with economic growth in Indonesia. Unidirectional causality is found between economic growth and the sukuk market development in Malaysia. And no causality (neutrality) is reported between the development of the Islamic stock market and economic growth in Malaysia. Meanwhile, trade openness has a significant and positive effect on the sukuk market development as well as economic growth in Malaysia. For the limitations, this research only focused on two countries and only delved into the corporation sukuk market.
\end{abstract}

Keywords: Islamic stock market, Sukuk, economic growth, trade openness, VECM.

JEL Classification: G15, G19, F49.

\section{Introduction}

The Islamic financial system, especially the Islamic financial market, is an alternative for the conventional financial system, which has a high level of volatility. The Islamic financial market refers to the Islamic principles, which operationally are usually in line with Islamic concepts. Besides offering wider access to companies to develop their businesses, the Islamic principle also protects related parties from exploitation, fraud, and unfairness between payoffs in conducting transactions. The rapid developments in the Islamic financial market are generally caused by the high increase in global sukuk issue value, whether government bonds or corporate bonds. Global sukuk issued have increased by about 272 times since 2001, from USD1.17 billion to become USD318.5 billion by the end of 2016 (IFSB 2017). Malaysia is in the first position as the country with the highest sukuk issue value at USD38,968 million, followed by Indonesia in the second position with a sukuk issue value of USD14,363 million (ICD 2017).

Islamic stock market developments and global sukuk market developments do not always go in the same direction. For instance, in 2016, the outstanding global sukuk experienced an increase of 6.06 percent to become USD318.5 billion [2015: USD300.3 billion]; while in the same year the Islamic stock market capitalization experienced a reduction of 4.5 percent to become USD22,120.4 billion [2015: USD23,181.8 billion]; similarly, certain Islamic stock markets and government sukuk markets have shown different movements from year to year.

According to Ahmed and Mmolainyane (2014), financial market development has a significant role in an economy's growth. Hence, in Islamic financial industry, it is also

Copyright $\odot 2019$ The Authors. Published by VGTU Press.

This is an Open Access article distributed under the terms of the Creative Commons Attribution License (http://creativecommons.org/licenses/by/4.0/), which permits unrestricted use, distribution, and reproduction in any medium, provided the original author and source are credited.. 
necessary to look at the relationship between stock market development, sukuk market development, and economic growth. In the conventional financial industry, much research has been conducted to see the relationship between stock market development, bond market development, and economic growth, but the research results show inconsistencies. Baele et al. (2010), Bansal et al. (2014), Chiang et al. (2014) stated that in the last two decades, the stock-bond relationship has changed dramatically, from being generally positive to being dominant negative. The negative relationship between stocks and bonds is due to the presence of the flight-to-quality phenomenon. This can be defined as an investor behavior or habit that shifts risky investments to safer investments. This phenomenon encourages investors to diversify between asset classes. Investors believe that the cross market relationship causes an increase in the probability of a financial contagion during a crisis period. Then during a financial crisis, it will influence a country's stock market to affect another country's stock market, which causes diversification in the international stock market to be less effective. Then investors will prefer to have assets with fixed returns like bonds as an alternative (Bordo and Murshid 2001). A different opinion was revealed from research results by Patoda and Jain (2012), Wanyama (2017) who stated that there is a unilateral positive relationship between bond market development and stock market development. Meanwhile, according to Muharam and Setyowati (2017), there is no relationship, whether unilateral or bidirectional between stock market development and bond market development in several countries.

Much research has been conducted related with the conventional financial market and economic growth, and the research results generally support the growth-nexus theory. Enisan and Olufisayo (2009), Marques et al. (2013), Pradhan et al. (2014) stated that there is a bi-directional relationship between stock market development and economic development. Meanwhile, according to Olweny and Kimani (2011), there is only a one-directional relationship between economic growth and stock market development, meaning that the stock market has a positive influence towards economic growth (supply leading hypothesis).

Likewise, previous research related with the relationship between the bond market and economic growth has varying results. Pradhan et al. (2015) conducted research on bond market development and economic growth in 20 countries. The research results revealed that in several cases, the bond market had a positive effect on economic growth (supply-leading hypothesis). In another location, it was discovered that economic growth influenced the bond market (demand-leading hypothesis). Next, it was also found that there was a reciprocal relationship between economic growth and bond market development (feedback hypothesis).
In the Islamic financial industry, research was also conducted to see the relationship between Islamic financial market development and economic growth. Research carried out by Said and Grassa (2013) revealed that economic growth has a positive influence on sukuk market development. On another side, sukuk market development also has a positive influence towards economic growth. Istiqomah (2012) stated that Islamic stock market development has a positive correlation towards economic growth. Nevertheless, research which looks at the relationship between the Islamic stock market and sukuk market is still very limited (Alam et al. 2013, Aloui et al. 2015, Naifar et al. 2016, Wahyudi et al., 2018). Moreover, there is no known previous research which specifically studied the relationship between sukuk market development and Islamic stock market development, whether by looking at one-directional relationship or bi-directional relationship. Therefore, further research is needed to see the relationship between Islamic stock market development and sukuk market development. It is also necessary to examine the relationship between the two markets with economic growth.

The purpose of this research is to look at the bi-directional (causality) relationship between Islamic stock market development, sukuk market development, and economic growth of a country. In addition, an examination is also conducted to find the relationships of the three variables with the level of trade openness of each country. According to Rajan and Zingales (2003) as well as Said and Grassa (2013), trade openness has a positive effect towards stock market development, bond market development, as well as sukuk market development through improvements in offers and requests (Endogenous Growth Theory). The countries chosen for the sample are Indonesia and Malaysia, as both countries have the biggest sukuk issue values in the world.

This is the first known research to examine the bi-directional (causality) relationship between the Islamic stock market development and the sukuk market development. It is also the first research to connect trade openness with the Islamic stock market. This research attempts to see whether there is a flight-to-quality phenomenon in the Islamic financial market, as well as tries to develop the Financegrowth Nexus Theory literature and the Endogenous Growth Theory literature to the Islamic financial industry. This study will beneficial to investors especially investors in Malaysia and Indonesia in order to formulate their investment strategy (i.e. portfolio strategy) in Islamic stock market and sukuk market.

\section{Review of literature}

\section{1. "Flight-to-quality" Phenomenon}

In literature related with the stock market and bond market, there is a "flight-to-quality" phenomenon, which explains 
that investors tend to shift their capital from risky investments like stocks to safer investments like bonds. This opinion is supported by Baur and Lucey (2009), Durand et al. (2009), Guler and Ozlale (2005), Robiyanto (2018a, 2018b, 2018c), Robiyanto et al. (2017a, 2017b). Their research results revealed that during a financial fluctuation period (financial crisis), investors tend to switch from high risk assets (like stocks) to safer assets (bonds). Mustafa et al. (2015) researched about whether there was a flightto-quality between a conventional financial market and a sukuk market. The research results showed that when conventional stock market volatility increases, investors tend to move to the sukuk market, as it is considered safer.

\subsection{Finance-growth Nexus Theory}

According to research conducted by Handriani and Robiyanto (2018), Ngare et al. (2014), the stock market has a positive influence towards economic growth. This is referred to as the "supply leading" hypothesis in developing the financial sector. This hypothesis states that the stock market causes economic growth, because the stock market stimulates the movement of unused funds to become productive and useful finances towards a country's economy. This opinion is also supported by research conducted by Atje and Jovanovic (1993), Yartey (2007), as well as Ho and Iyke (2017).

Next, in the Finance-growth Nexus Theory, there is another argument called the "demand following" hypothesis. According to this viewpoint, developments in the financial sector are stimulated by economic growth. Developments in the financial sector are facilitated by real economic sector growth (Robinson 1952, Romer 1990). The argument is that when a country's economy grows and develops, the surplus will be collected and then will improve the financial market, including the stock market. This statement is supported by research conducted by Marques et al. (2013), Pradhan et al. (2014). The third viewpoint is the "feedback" hypothesis. This perspective states that there is a bi-directional relationship between financial developments and economic growth with the relationship characteristic dependent on the stage of economic growth (Levine 1997, Luintela and Khan 1999, Schumpeter 1912).

Research on the sukuk market that was carried out by Said and Grassa (2013) conveyed that economic growth has a positive influence on the development of the sukuk market. On another side, research done by Smaoui and Nechi (2017) revealed that economic growth has a positive influence towards sukuk market development.

\subsection{Endogenous Growth theory}

Next, literature revealed the advantages of trade openness towards the financial market in two ways. First, trade openness stimulates financial market growth by increasing the demand towards financial products and services. This demand is increased due to an increase in income risk and volatility that is related with trade openness (Mohd et al. 2013, Newbery and Stiglitz 1984, Svaleryd and Vlachos 2002, Vazakidis and Adamopoulos 2009). Second, trade openness is beneficial for financial market growth through increasing stock market offers (Braun and Raddatz 2005, Rajan and Zingales 2003). The stock market and sukuk market will be more developed in an economy that tends to be more open, because when the level of openness of an economy is high, access towards foreign financing from foreign investors will be easily obtained. Therefore, it will increase sukuk market development and Islamic stock market development. Said and Grassa (2013) discovered that trade openness has a positive and significant influence towards sukuk market development in Saudi Arabia, Kuwait, Bahrain, Qatar, Indonesia, UAE, Malaysia, Pakistan, Brunei, and Gambia.

\section{Data}

The data used in this research was from monthly time series data that consisted of Islamic stock market capitalization, outstanding corporation sukuk, gross domestic product (GDP) value, as well as export and import values from May 2011 - December 2017 for Indonesia and from March 2008 - December 2017 for Malaysia. The data sources in this research were obtained from the Bloomberg Database, the Indonesia Financial Service Authority website, and FAST Bank Malaysia.

\section{Variables}

Four variables were used in this research, including Islamic stock market development, sukuk market development, economic growth, and trade openness. The Islamic stock market development (PPSA) was proxied by a country's Islamic stock market capitalization, which can be formulated as follows:

$$
P P S A=\frac{K P S A_{t}-k K P S A_{t-1}}{K P S A_{t-1}},
$$

where: $K P S A_{t}=t$ month Islamic stock market capitalization; $K P S A_{t-1}=t-1$ month Islamic stock market capitalization.

The variable sukuk market development (PPS) is proxied by outstanding corporation sukuk, which is formulated as follows:

$$
P P S=\frac{O T S_{t}-O T S_{t-1}}{O T S_{t-1}},
$$

where: $O T S_{t}=t$ month outstanding corporation sukuk; $O_{T S}=t-1$ month outstanding corporation sukuk.

The variable economic growth (PE) is proxied by the gross domestic product (GDP) value growth, which is formulated as follows:

$$
P E=\frac{P D B_{t}-P D B_{t-1}}{P D B_{t-1}},
$$


where: $P D B_{t}=t$ month real gross domestic product value; $P D B_{t-1}=t-1$ real gross domestic product value.

This is similar with the variable trade openness which is proxied by the trading ratio growth (number of exports and imports) towards a country's gross domestic product, which is formulated as follows:

$$
T O=\frac{T O_{t}-T O_{t-1}}{T O_{t-1}},
$$

where: $T O_{t}$ - trading ratio towards $t$ month gross domestic product; $\mathrm{TO}_{t-1}$ - trading ratio towards $t-1$ month gross domestic product.

Although this study used limited variables mentioned above, this study used sophisticated method that will add the complexity of those variables (i.e. by using several lags based on preliminary analysis results that showed in Table 1 and Table 2 in results section.

\section{Analysis method}

First, an interpolation of the quarterly data was done to become monthly data towards the gross domestic product of Indonesia and Malaysia. Likewise, with the market development data and economic growth data, it was calculated before the analysis process was conducted. Next, a stationarity analysis was done towards the data used in this research. A stationary test was used with an Augmented Dickey-Fuller statistics (Dickey and Fuller 1979). Then the long-term relationships between variables were examined by using a cointegration test that was developed by Johansen and Juselius (1990). Next, the relationships between variables were seen by using a Vector Auto-Regressive (VAR) analysis or a Vector Error Correction Model (VECM) if the stationary data was in the first difference level and there was cointegration between variables. Finally, the Granger causality test was carried out to see the directions of relationships between variables.

\subsection{Unit Root Test and Johansen Cointegration Test}

Before conducting an analysis using time series data, it is first necessary to see whether the time series data is stationary at the same level or not (Robiyanto and Ernayani 2018, Suganda et al. 2018). An Augmented Dickey-Fuller (ADF) test was done to see whether there was a root unit or not in the time series data used in this research. Unit root test done by using level at first, if the Augmented DickeyFuller (ADF) statistics show that there is a unit root, so unit root test by using first difference will be conducted, while second difference will also apply if the Augmented Dickey-Fuller (ADF) statistics in first difference show that there is a unit root.

This study also do a Johansen cointegration test. The results of the cointegration test can be found by comparing the trace test value and maximum-Eigen value test with the critical value (Robiyanto 2017, Wang and Chueh 2013). Cointegration occurs when the trace test value and maxEigen value test are bigger than the critical value.

\subsection{Vector Error Correction Model (VECM) and the VECM Granger Causality Test}

If the stationary data is at the first difference level and there is cointegration between variables, then an analysis is conducted by using the Vector Error Correction Model (Engle and Granger 1987). In contrast, the VAR method is used if the variables are not cointegrated with each other (Granger 1969). The VECM method is used to see the short-term and long-term relationships between endogen variables in Islamic stock market development, sukuk market development, and economic growth. It also looks at the influence of trade openness on the three endogen variables.

The equations of the VECM model are stated as follows:

$$
\begin{aligned}
& \Delta P P S_{t}=a_{1}+\beta_{1\left(e_{t-1)}\right.}+\sum_{k=1}^{n} \gamma_{1} \Delta P P S_{t-1}+\sum_{k=1}^{n} \gamma_{2} \Delta P P S A_{t-1}+ \\
& \sum_{k=1}^{n} \gamma_{3} \Delta P E_{t-1}+\gamma_{4} \Delta T O_{t}+\varepsilon_{1 t} ; \\
& \Delta P P S A_{t}=a_{2}+\beta_{2\left(e_{t-1)}\right.}+\sum_{k=1}^{n} \gamma_{1} \Delta P P S A_{t-1}+\sum_{k=1}^{n} \gamma_{2} \Delta P P S_{t-1}+ \\
& \sum_{k=1}^{n} \gamma_{3} \Delta P E_{t-1}+\gamma_{4} \Delta T O_{t}+\varepsilon_{2 t} ; \\
& \Delta P E_{t}=a_{3}+\beta_{3\left(e_{t-1)}\right.}+\sum_{k=1}^{n} \gamma_{1} \Delta P E_{t-1}+\sum_{k=1}^{n} \gamma_{2} \Delta P P S_{t-1}+ \\
& \sum_{k=1}^{n} \gamma_{3} \Delta P P S A_{t-1}+\gamma_{4} \Delta T O_{t}+\varepsilon_{3 t},
\end{aligned}
$$

$\triangle P P S_{t}$ is the level of sukuk market development at a certain period, $\triangle P P S A_{t}$ is the Islamic stock market development at a certain period, and $\triangle P E_{t}$ is the level of economic growth at a certain period.

The causality relationships between the variables of Islamic stock market development, sukuk market development, and economic growth were researched using the Granger causality framework. The Granger causality equations that were developed from the VECM framework are listed as follows:

$$
\begin{aligned}
& \Delta P P S_{t}=\beta_{0}+\sum_{j=1}^{p} \beta_{1 j} \Delta P P S_{t-j}+\sum_{j=0}^{p} \beta_{2 j} \Delta P P S A_{t-J}+ \\
& \sum_{j=0}^{p} \beta_{3 j} \Delta P E_{t-j}+\mu_{1 t} ; \\
& P P S A_{t}=\beta_{0}+\sum_{j=1}^{p} \beta_{1 j} \Delta P P S_{t-j}+\sum_{j=0}^{p} \beta_{2 j} \Delta P P S A_{t-J}+ \\
& \sum_{j=0}^{p} \beta_{3 j} \Delta P E_{t-j}+\mu_{1 t} ;
\end{aligned}
$$




$$
\begin{aligned}
& P E_{t}=\beta_{0}+\sum_{j=1}^{p} \beta_{1 j} \Delta P P S_{t-j}+\sum_{j=0}^{p} \beta_{2 j} \Delta P P S A_{t-J}+ \\
& \sum_{j=0}^{p} \beta_{3 j} \Delta P E_{t-j}+\mu_{3 t} .
\end{aligned}
$$

\section{Results}

\subsection{Unit Root test results}

The test results of the stationary data in Indonesia and Malaysia can be seen in Table 1. Based on Table 1, it was found that none of the variables were stationary at level $1(0)$, whether at a significance level of $1 \%, 5 \%$, or $10 \%$. Then a unit root test was conducted at level 1(1).

The unit root test of ADF 1(1) revealed that the data used in this research was stationary at the first difference
1(1) level. This means that the data was integrated in order 1. For variables that were not stationary at the level, then there was a big possibility that there would be cointegration or long-term relationships between variables (Robiyanto and Ernayani 2018). Therefore, further analysis by using Johansen Cointegration test was done to see whether there were long-term relationships (cointegration) between the variables used in the research.

\subsection{Johansen Cointegration test results}

A cointegration test for variables in Indonesia was performed by adding lag 6 , and for Malaysia it was done by adding lag 3. The cointegration test results of the related variables in the two countries are shown in Table 2.

The Max-Eigen value test indicates 3 cointegrating eqn(s) at the 0.05 level.

\begin{tabular}{|c|c|c|c|c|}
\hline \multicolumn{5}{|c|}{ Malaysia } \\
\hline \multirow{2}{*}{ Variable } & \multicolumn{2}{|c|}{ Prob. } & \multicolumn{2}{|c|}{ first difference } \\
\hline & ADF t-statistic & level & ADF t-statistic & Prob. \\
\hline PPSA & $-9.814598^{\star * *}$ & 0.0000 & $-8.651597^{* * *}$ & 0.0000 \\
\hline$P P S$ & $-10.41717^{\star * *}$ & 0.0001 & $-10.54909^{\star * *}$ & 0.0000 \\
\hline$P E$ & -3.024374 & 0.1305 & $-11.36764^{* * *}$ & 0.0000 \\
\hline TO & $-13.89034^{* * *}$ & 0.0000 & $-7.685270^{* * *}$ & 0.0000 \\
\hline \multicolumn{5}{|c|}{ Indonesia } \\
\hline \multirow{2}{*}{ Variable } & \multicolumn{2}{|c|}{ Prob. } & \multicolumn{2}{|c|}{ first difference } \\
\hline & ADF t-statistic & level & ADF t-statistic & Prob. \\
\hline PPSA & $-8.547421^{* * *}$ & 0.0000 & $-10.17676^{* * *}$ & 0.0000 \\
\hline PPS & $-11.31635^{\star * *}$ & 0.0001 & $-7.712835^{\star * *}$ & 0.0000 \\
\hline$P E$ & -2.385577 & 0.3837 & $-14.04581^{* * *}$ & 0.0000 \\
\hline TO & $-9.786483^{\star * \star}$ & 0.0000 & $-6.577121^{\star * *}$ & 0.0000 \\
\hline
\end{tabular}

Table 1. Augmented Dickey-Fuller (ADF) test results (source: secondary data, processed)

${ }^{* * *}$ significant at the $1 \%$ significance level.

\begin{tabular}{|c|c|c|c|c|c|}
\hline \multicolumn{6}{|c|}{ Malaysia } \\
\hline \multirow{2}{*}{$\mathrm{H} 0$} & \multirow[t]{2}{*}{$\mathrm{Ha}$} & \multirow{2}{*}{$\begin{array}{c}\text { Trace } \\
\text { statistic }\end{array}$} & \multirow{2}{*}{$\frac{\text { Max-Eigen value }}{\text { statistic }}$} & \multicolumn{2}{|c|}{ Critical Value (0.05) } \\
\hline & & & & Trace test & Max-Eigen test \\
\hline$r=0$ & $\mathrm{r}=1$ & $158.2869^{\star *}$ & $67.71547^{\star \star}$ & 24.27596 & 17.79730 \\
\hline $\mathrm{r} \leq 1$ & $r=2$ & $90.57138^{\star *}$ & $55.83486^{\star *}$ & 12.32090 & 11.22480 \\
\hline$r \leq 2$ & $r=3$ & $34.73653^{\star *}$ & $34.73653^{* *}$ & 4.129906 & 4.129906 \\
\hline
\end{tabular}

Table 2. Johansen Cointegration test results (source: secondary data, processed)

\begin{tabular}{|c|c|c|c|c|c|}
\hline \multicolumn{6}{|c|}{ Indonesia } \\
\hline \multirow{2}{*}{ Ho } & \multirow{2}{*}{$\mathrm{Ha}$} & \multirow{2}{*}{$\begin{array}{c}\text { Trace } \\
\text { statistic }\end{array}$} & \multirow{2}{*}{$\begin{array}{c}\text { Max-Eigen value } \\
\text { statistic }\end{array}$} & \multicolumn{2}{|c|}{ Critical Value (0.05) } \\
\hline & & & & Trace test & Max-Eigen test \\
\hline$r=0$ & $\mathrm{r}=1$ & $114.1773^{\star *}$ & $46.31881^{\star *}$ & 24.27596 & 17.79730 \\
\hline$r \leq 1$ & $r=2$ & $67.85846^{* *}$ & $36.10433^{* *}$ & 12.32090 & 11.22480 \\
\hline$r \leq 2$ & $r=3$ & $31.75413^{* *}$ & $31.75413^{\star *}$ & 4.129906 & 4.129906 \\
\hline
\end{tabular}

\footnotetext{
** significant at the $1 \%$ significance level.
} 
Based on the cointegration test results in Table 2, it was found that whether in Indonesia or Malaysia, the trace test and Max-Eigen test significantly rejected the hypothesis (H0) $r=0, r \leq 1, r \leq 2$ at a $5 \%$ significance level. Then it accepted $\mathrm{Ha} r=1, r=2$, and $r=3$. This indicates that there were three cointegration equations between the variables researched. So it proved that research method used in this study is conforms with the data. This finding also implied that there are long-term relationships (cointegration) between Islamic stock market development, sukuk market development, and economic growth in Indonesia and Malaysia.

\subsection{Vector Error Correction Model (VECM)}

Since there was stationary data at the first difference level and cointegration between variables, to see the relationships between sukuk market development, economic growth, and trade openness, a Vector Error Correction Model method was fit to use in this study. The VECM test results for Malaysia and Indonesia are revealed in Table 3 and Table 4.

The VECM test results in Malaysia reveal that for the long-term, economic growth in the first lag is 0.57726 $(<1.66)$, which does not have a significant influence towards sukuk market development. This means that long-term, the increase or decrease of economic growth will not influence sukuk market development. On another side, Islamic stock market development is $-6.89104(<1.66)$, which has a significant and negative influence on sukuk market development. This means that an increase in Islamic stock market development of 1 percent will be followed by a reduction in sukuk market development of 6.89 percent.

In the short-term, sukuk-market development has a negative influence towards Islamic stock market development, and Islamic stock market development also has a significant and negative influence towards sukuk market development in all periods in Malaysia. It was found that economic growth does not have a significant influence towards Islamic stock market development, and the Islamic stock market also does not significantly influence economic growth. Next, it was discovered that in Malaysia, economic growth has a significant and negative influence towards sukuk market development. Then trade openness was seen to have a positive influence towards sukuk market development and economic growth, but it does not have a significant influence towards Islamic stock market development.

In Indonesia, the VECM test results reveal that longterm, economic growth in the first lag is $-2.57743(>1.66)$, which has a significant and negative influence on sukuk market development of -3.316443 . This implies that longterm, an increase of economic growth of 1 percent will reduce Indonesia's sukuk market development by 3.3 percent. On another side, Islamic stock market development of 4.30135 (>1.66) has a significant and positive influence on sukuk market development. This means that an increase in stock market development of 1 percent will be followed by an increase of Islamic stock market development of 2.39 percent.

In the short-term in Indonesia, sukuk market development has a significant and positive influence towards Islamic stock market development from period 1 to period 5, and Islamic stock market development has a significant and positive influence towards sukuk market development from period 1 to period 5. Economic growth has a significant

Table 3. Vector Error Correction Model Estimation for Malaysia (source: secondary data, processed)

\begin{tabular}{|c|c|c|c|}
\hline \multicolumn{4}{|c|}{ Long-term } \\
\hline \multicolumn{2}{|c|}{ Cointegrating Eq: } & \multicolumn{2}{|c|}{ CointEq1 } \\
\hline \multicolumn{2}{|c|}{ DPPS(-1) } & \multicolumn{2}{|c|}{1} \\
\hline & \multicolumn{2}{|c|}{$2.391528^{\star * *}$} \\
\hline \multicolumn{2}{|c|}{ DPPSA(-1) } & \multicolumn{2}{|c|}{ [ 4.30135$]$} \\
\hline \multicolumn{2}{|c|}{$\mathrm{DPE}(-1)$} & \multicolumn{2}{|c|}{$-3.316443^{\star \star}$} \\
\hline & & \multicolumn{2}{|c|}{$[-2.57743]$} \\
\hline \multicolumn{4}{|c|}{ Short-term } \\
\hline $\begin{array}{c}\text { Error } \\
\text { Correction: }\end{array}$ & D(DPPS) & D(DPPSA) & $\mathrm{D}(\mathrm{DPE})$ \\
\hline $\begin{array}{c}\text { Speed of adjus- } \\
\text { tment }\end{array}$ & $-1.172397^{* * *}$ & $2.732837^{\star \star *}$ & -0.028585 \\
\hline (EC term) & {$[-5.10338]$} & [6.51303] & {$[-0.19844]$} \\
\hline \multirow[t]{2}{*}{$\mathrm{D}(\mathrm{DPPS}(-1))$} & -0.177765 & $-2.161818^{\star * *}$ & 0.054366 \\
\hline & {$[-0.88435]$} & {$[-5.88818]$} & {$[0.43133]$} \\
\hline \multirow[t]{2}{*}{$\mathrm{D}(\mathrm{DPPS}(-2))$} & $-0.324693^{\star \star}$ & $-1.553314^{\star * *}$ & 0.084739 \\
\hline & {$[-2.19067]$} & {$[-5.73785]$} & [0.91177] \\
\hline \multirow[t]{2}{*}{$\mathrm{D}(\mathrm{DPPS}(-3))$} & $-0.155490^{*}$ & $-0.660227^{\star * *}$ & 0.023413 \\
\hline & {$[-1.67809]$} & {$[-3.90116]$} & {$[0.40297]$} \\
\hline \multirow[t]{2}{*}{$\mathrm{D}(\mathrm{DPPSA}(-1))$} & $-0.593315^{\star * *}$ & 0.302990 & -0.022892 \\
\hline & {$[-4.48342]$} & [1.25354] & {$[-0.27588]$} \\
\hline \multirow[t]{2}{*}{$\mathrm{D}(\mathrm{DPPSA}(-2))$} & $-0.340822^{\star * *}$ & -0.028981 & -0.022933 \\
\hline & {$[-3.58255]$} & {$[-0.16679]$} & {$[-0.38444]$} \\
\hline \multirow[t]{2}{*}{$\mathrm{D}(\mathrm{DPPSA}(-3))$} & $-0.144604^{* * *}$ & 0.010486 & 0.013773 \\
\hline & {$[-2.75056]$} & {$[0.10920]$} & {$[0.41780]$} \\
\hline \multirow[t]{2}{*}{$\mathrm{D}(\mathrm{DPE}(-1))$} & 0.167107 & -0.183613 & -0.679380 \\
\hline & [1.13073] & {$[-0.68023]$} & {$[-7.33128]^{* * *}$} \\
\hline \multirow[t]{2}{*}{$\mathrm{D}(\mathrm{DPE}(-2))$} & -0.015178 & 0.168721 & $-0.254437^{\star *}$ \\
\hline & {$[-0.08886]$} & {$[0.54082]$} & {$[-2.37566]$} \\
\hline \multirow[t]{2}{*}{$\mathrm{D}(\mathrm{DPE}(-3))$} & $-0.326493^{\star *}$ & -0.308817 & $-0.439558^{\star * *}$ \\
\hline & {$[-2.22762]$} & {$[-1.15360]$} & {$[-4.78284]$} \\
\hline \multirow[t]{2}{*}{ DTO } & $0.034726^{*}$ & 0.026485 & $0.028476^{\star *}$ \\
\hline & [1.85287] & {$[0.77372]$} & [2.42309] \\
\hline
\end{tabular}

$* * *,{ }^{* *},{ }^{*}$ sequentially show a significance level of $1 \%, 5 \%$, and $10 \% *$; $\mathrm{D}$ is the first-difference, while [ ] is the t-statistic. 
Table 4. Vector Error Correction Model Estimation for Indonesia (source: secondary data, processed)

\begin{tabular}{|c|c|c|c|}
\hline \multicolumn{4}{|c|}{ Long-term } \\
\hline \multicolumn{2}{|c|}{ Cointegrating Eq: } & \multicolumn{2}{|c|}{ CointEq1 } \\
\hline \multicolumn{2}{|c|}{ DPPS $(-1)$} & \multicolumn{2}{|c|}{1} \\
\hline \multicolumn{2}{|c|}{$\operatorname{DPPSA}(-1)$} & \multicolumn{2}{|c|}{$2.391528^{\star * \star}$} \\
\hline & \multicolumn{2}{|c|}{$[4.30135]$} \\
\hline \multicolumn{2}{|c|}{$\mathrm{DPE}(-1)$} & \multicolumn{2}{|c|}{$-3.316443^{\star *}$} \\
\hline & & \multicolumn{2}{|c|}{$[-2.57743]$} \\
\hline \multicolumn{4}{|c|}{ Short-term } \\
\hline $\begin{array}{c}\text { Error } \\
\text { Correction: }\end{array}$ & $\mathrm{D}(\mathrm{DPPS})$ & D(DPPSA) & $\mathrm{D}(\mathrm{DPE})$ \\
\hline $\begin{array}{c}\text { Speed of } \\
\text { adjustment }\end{array}$ & -3.468079 & -0.864287 & 0.149129 \\
\hline$(\mathrm{EC}$ term $)$ & {$[-4.55378]$} & {$[-3.28745]$} & {$[2.76530]$} \\
\hline \multirow[t]{2}{*}{$\mathrm{D}(\mathrm{DPPS}(-1))$} & $1.679239^{* *}$ & $0.812942^{\star * *}$ & $-0.135544^{\star * *}$ \\
\hline & {$[2.35438]$} & {$[3.30173]$} & {$[-2.68375]$} \\
\hline \multirow[t]{2}{*}{$\mathrm{D}(\mathrm{DPPS}(-2))$} & 1.038197 & $0.764012^{\star \star \star}$ & $-0.103665^{\star *}$ \\
\hline & {$[1.65661]$} & {$[3.53151]$} & {$[-2.33600]$} \\
\hline \multirow[t]{2}{*}{$\mathrm{D}(\mathrm{DPPS}(-3))$} & 0.642040 & $0.603538^{* * *}$ & $-0.076204^{\star *}$ \\
\hline & {$[1.21150]$} & {$[3.29901]$} & {$[-2.03065]$} \\
\hline \multirow[t]{2}{*}{$\mathrm{D}(\mathrm{DPPS}(-4))$} & 0.283552 & $0.368940^{* *}$ & $-0.049492^{*}$ \\
\hline & {$[0.68874]$} & {$[2.59595]$} & {$[-1.69766]$} \\
\hline \multirow[t]{2}{*}{$\mathrm{D}(\mathrm{DPPS}(-5))$} & -0.060516 & $0.193542^{*}$ & $-0.032746^{*}$ \\
\hline & {$[-0.22678]$} & [2.10097] & {$[-1.73291]$} \\
\hline \multirow[t]{2}{*}{$\mathrm{D}(\mathrm{DPPS}(-6))$} & -0.117846 & 0.029387 & -0.013603 \\
\hline & {$[-0.91728]$} & {$[0.66262]$} & {$[-1.49522]$} \\
\hline \multirow[t]{2}{*}{$\mathrm{D}(\mathrm{DPPSA}(-1))$} & $6.932915^{\star * *}$ & 0.517754 & $-0.334422^{\star \star \star}$ \\
\hline & {$[4.07384]$} & {$[0.88131]$} & {$[-2.77511]$} \\
\hline \multirow[t]{2}{*}{ D(DPPSA $(-2))$} & $5.726256^{\star * *}$ & 0.178607 & $-0.292947^{\star * *}$ \\
\hline & {$[3.85181]$} & {$[0.34803]$} & {$[-2.78279]$} \\
\hline \multirow[t]{2}{*}{$\mathrm{D}(\mathrm{DPPSA}(-3))$} & $4.424228^{\star * *}$ & 0.187323 & $-0.232296^{\star *}$ \\
\hline & [3.54482] & {$[0.43478]$} & {$[-2.62843]$} \\
\hline \multirow[t]{2}{*}{ D(DPPSA $(-4))$} & $3.373433^{* * *}$ & 0.145454 & $-0.167550^{* *}$ \\
\hline & [3.36273] & {$[0.42001]$} & {$[-2.35864]$} \\
\hline $\mathrm{D}(\mathrm{DPPSA}(-5))$ & $2.135894^{\star \star \star \star}$ & 0.020800 & -0.077853 \\
\hline & {$[3.02678]$} & [0.08539] & {$[-1.55802]$} \\
\hline $\mathrm{D}(\mathrm{DPPSA}(-6))$ & $1.042581^{\star * *}$ & 0.045548 & -0.032473 \\
\hline & [2.79993] & {$[0.35434]$} & {$[-1.23158]$} \\
\hline $\mathrm{D}(\mathrm{DPE}(-1))$ & $-8.054813^{* * *}$ & $-2.837314^{\star * *}$ & $-0.322241^{\star}$ \\
\hline & {$[-3.28553]$} & {$[-3.35255]$} & {$[-1.85621]$} \\
\hline $\mathrm{D}(\mathrm{DPE}(-2))$ & $-5.508150^{* *}$ & $-2.313687^{\star * *}$ & -0.094845 \\
\hline & {$[-2.23373]$} & [-2.71799] & {$[-0.54317]$} \\
\hline $\mathrm{D}(\mathrm{DPE}(-3))$ & $-3.947268^{\star}$ & -1.145853 & $-0.283823^{\star}$ \\
\hline & {$[-1.68918]$} & {$[-1.42045]$} & {$[-1.71524]$} \\
\hline $\mathrm{D}(\mathrm{DPE}(-4))$ & -0.869535 & $-1.268407^{\star}$ & -0.082255 \\
\hline & {$[-0.42002]$} & {$[-1.77486]$} & {$[-0.56111]$} \\
\hline $\mathrm{D}(\mathrm{DPE}(-5))$ & 0.432760 & $-1.508480^{\star *}$ & 0.055079 \\
\hline & {$[0.22848]$} & {$[-2.30710]$} & {$[0.41067]$} \\
\hline $\mathrm{D}(\mathrm{DPE}(-6))$ & 1.053731 & $-0.981097^{\star}$ & -0.271034 \\
\hline & {$[0.64567]$} & {$[-1.74146]$} & {$[-2.34534]$} \\
\hline DTO & -0.144022 & 0.023604 & $5.30 \mathrm{E}-05$ \\
\hline & {$[-1.40356]$} & {$[0.66635]$} & {$[0.00730]$} \\
\hline
\end{tabular}

***, **,* sequentially show a significance level of $1 \%, 5 \%$, and $10 \%$; $\mathrm{D}$ is the first-difference, while [ ] is the t-statistic. and negative influence towards Islamic stock market development. Likewise, Islamic stock market development has a significant and negative influence towards economic growth. Next, it was revealed that economic growth has a significant and negative influence towards sukuk market development in Indonesia. Similarly, sukuk market development has a significant and negative influence towards economic growth. Trade openness was found to not have a significant influence, whether towards sukuk market development, Islamic stock market development, or economic growth in Indonesia.

\subsection{VECM Short-run and Long-run Granger causality results}

A causality relationship will be difficult to estimate when using the VAR model, if the variables used are cointegrated with each other (Engle and Granger 1987). Therefore, in this research, a causality test was done with the Granger Causality-Block Exogeneity Wald test, which was developed from the Vector Error Correction Model (VECM). In the VECM framework, the short-term and long-term causality relationships can be researched.

Table 5 reveals the Granger causality test results for Malaysia. From this table, it was discovered that the correction term (ECT) $t$-statistic value, the PPSA p-value, and $\mathrm{PE}$ are significant in the PPS equation. This means that in the short-term or long-term, sukuk market development is caused by Islamic stock market development and economic growth. Next, it was found that the coefficients correction term (ECT) and PPS are significant in the PPSA equation, which means that whether short-term or long-term, Islamic stock market development is caused by sukuk market development. Meanwhile, in the PE equation, no significant coefficients were found, whether in the PPS variable, the PPSA variable, or the correction term (ECT) coefficient.

Then it can be concluded that in Malaysia, there is a two-way causality relationship between sukuk market development and Islamic stock market development, whether short-term or long-term. There is a one-way causality relationship from economic growth to sukuk market development for short-term and long-term. Next, neutrality (no causality) was discovered between Islamic stock market development and economic growth.

Table 6. provides the results from the Granger causality test for Indonesia. It was revealed that the p-value and $\mathrm{t}$-statistic value of the correction term (ECT) all have significant variables at the $1 \%, 5 \%$, and $10 \%$ levels in the three equations. Therefore, it can be concluded that in Indonesia, there is a two-way causality relationship between Islamic stock market development and sukuk market development, whether short-term or long-term. Then it was discovered that there is a two-way causality relationship, short-term and long-term, between Islamic stock market development 
Table 5. VEC Granger Causality-Block Exogeneity Wald test results for Malaysia

\begin{tabular}{|c|c|c|c|c|}
\hline \multirow{3}{*}{$\begin{array}{l}\text { Dependent } \\
\text { Variables }\end{array}$} & \multicolumn{3}{|c|}{ Independent Variables } & \multirow{3}{*}{$\begin{array}{l}\text { Long-run } \\
E C T_{t-1}\end{array}$} \\
\hline & \multicolumn{3}{|c|}{ Short-run } & \\
\hline & $D(D P P S)$ & $D(D P P S A)$ & $D(D P E)$ & \\
\hline$D(D P P S)$ & - & $\begin{array}{c}22.56010^{* * *} \\
(0.0000)\end{array}$ & $\begin{array}{c}7.036960^{*} \\
(0.0707)\end{array}$ & $\begin{array}{c}-1.172397^{\star * *} \\
{[-5.10338]}\end{array}$ \\
\hline$D(D P P S A)$ & $\begin{array}{c}36.62262^{\star * *} \\
(0.0000)\end{array}$ & - & $\begin{array}{c}5.512106 \\
(0.1379)\end{array}$ & $\begin{array}{c}2.732837^{\star * *} \\
{[6.51303]}\end{array}$ \\
\hline$D(D P E)$ & $\begin{array}{c}1.947183 \\
(0.5834)\end{array}$ & $\begin{array}{c}2.028106 \\
(0.5666)\end{array}$ & - & $\begin{array}{l}-0.028585 \\
{[-0.19844]}\end{array}$ \\
\hline
\end{tabular}

${ }^{* * *},{ }^{* *},{ }^{*}$ sequentially show a significance level of $1 \%, 5 \%$, and $10 \%$. The p-value is shown in ( ), and [ ] is a t-statistic. $D=$ first difference, while $P P S=$ sukuk market development equation. $P P S A=$ Islamic stock market development, while $P E=$ economic growth .

Table 6. VEC Granger Causality-Block Exogeneity Wald test results for Indonesia

\begin{tabular}{|c|c|c|c|c|}
\hline \multirow{3}{*}{$\begin{array}{l}\text { Dependent } \\
\text { Variables }\end{array}$} & \multicolumn{3}{|c|}{ Independent Variables } & \multirow{3}{*}{$\begin{array}{l}\text { Long-run } \\
E C T_{t-1}\end{array}$} \\
\hline & \multicolumn{3}{|c|}{ Short-run } & \\
\hline & $D(D P P S A)$ & $D(D P P S A)$ & $D(D P E)$ & \\
\hline$D(D P P S)$ & - & $\begin{array}{c}18.05283^{* * *} \\
(0.0061)\end{array}$ & $\begin{array}{c}13.17998^{\star *} \\
(0.0403)\end{array}$ & $\begin{array}{c}-3.468079^{* * *} \\
{[-4.55378]}\end{array}$ \\
\hline$D(D P P S A)$ & $\begin{array}{c}19.23307^{\star * *} \\
(0.0038)\end{array}$ & - & $\begin{array}{c}19.61919^{* * *} \\
(0.0032)\end{array}$ & $\begin{array}{c}-0.864287^{\star * *} \\
{[-3.28745]}\end{array}$ \\
\hline$D(D P E)$ & $\begin{array}{c}10.70536 * \\
(0.0979)\end{array}$ & $\begin{array}{c}10.87406^{*} \\
(0.0923)\end{array}$ & - & $\begin{array}{c}0.149129^{* * *} \\
{[2.76530]}\end{array}$ \\
\hline
\end{tabular}

${ }^{* * *},{ }^{* *},{ }^{*}$ sequentially show a significance level of $1 \%, 5 \%$, and $10 \%$. The p-value is shown in ( ), and the t-statistic is shown in [ ]. $D=$ first difference, while $P P S=$ sukuk market development equation. $P P S A=$ Islamic stock market development, while $P E=$ economic growth.

and economic development. There is also a two-way causality relationship, short-term and long-term, between sukuk market development and economic growth.

\section{Results and discussion}

\subsection{Relationship between Sukuk market development and Islamic stock market development}

From the VECM estimation results of Table 5 and Table 6, it can be concluded that there is a two-way relationship or reciprocal relationship between both markets. Islamic stock development has an influence towards sukuk market development, and the sukuk market has an influence towards the Islamic stock market development. These results are supported by the Granger causality test, which demonstrates that there is a two-way causality relationship (bi-directional causality) between Islamic stock market development and sukuk market development in Indonesia and Malaysia, whether short-term or long-term.

However, between the two countries, there is a difference in the relationship direction. In Indonesia, the Islamic stock market and sukuk market have a positive relationship. Meanwhile, in Malaysia, both markets have a negative relationship. The sukuk market has a negative relationship towards the Islamic stock market in Malaysia, showing that the sukuk market and stock market move in opposing directions. Therefore, it can be said that in Malaysia the Islamic capital market has a flight-to-quality phenomenon. These results are in line with previous research conducted by Mustafa et al. (2015), who found a flight-to-quality phenomenon in the Malaysian sukuk market. Meanwhile, in the Indonesian Islamic capital market, no flight-to-quality phenomenon is found. Malaysian sukuk market is the largest sukuk market in the world which have around 51\% global sukuk outstanding, while Indonesian sukuk market only have 7.3\% global sukuk outstanding (Mohamed 2018). As the largest sukuk market, Malaysia have a lot of global investor which sensitive to global financial condition, also Malaysian investor in Islamic stock market recognizes that fixed income instruments (i.e. sukuk) can act as safe haven instrument in order to flight-to-quality (Robiyanto 2018a). So it is not surprised if the sukuk market and stock market move in opposite directions in Malaysia. The different result found in Indonesia, because most Indonesian sukuk investors tend to hold sukuk to maturity, so sukuk supply in Indonesian market is limited. But there are small number of investors who will trade sukuk in limited volume in order to fulfill their liquidity, and this kind of investors is sensitive to Islamic stock market condition, hence the relationship between Islamic stock market and sukuk market in Indonesia is positive. 


\subsection{Causality relationship between economic growth and Islamic stock market development}

There is a two-way causality relationship (bi-directional causality), short-term and long-term, between Islamic stock market development and economic growth in Indonesia. These results are supported by previous research carried out by Enisan and Olufisayo (2009), Marques et al. (2013), Pradhan et al. (2014) in the conventional financial industry.

Different with the Growth Nexus Theory, in the Islamic financial market, it was revealed that there is a negative two-way relationship between stock market development and economic growth. The economic growth, which has a negative influence towards stock market development in Indonesia, depicts that investors prefer the Islamic financial industry when the economy is in recession. On another side, the Islamic stock market also can retard economic growth, because there is a lack of savings due to the financial capital accumulation externality, as well as ownership which spreads also has a negative effect towards company management, including public company performance that will slow down economic growth (Bhide 1993, Newbery and Stiglitz 1984).

Different results were revealed in Malaysia, where there is neutrality, meaning there is no relationship, whether one-directional or two-directional, between Islamic stock market development and economic growth. These results are supported by studies conducted by Pradhan et al. (2015) as well as Muharam and Setyowati (2017), who revealed that there is a neutrality relationship between economic growth and stock market development in the countries researched.

\subsection{Causality relationship between Sukuk market development and economic growth}

It was discovered that there is a two-directional relationship or bi-directional causality between sukuk market development and economic growth in Indonesia. Meanwhile, in Malaysia, there is only a one-way relationship (one-directional causality), meaning economic growth causes sukuk market development. The research results show there is a negative influence between sukuk market development and economic growth in Malaysia, which supports the existence of the flight-to-quality phenomenon in the Islamic financial industry. When the economy is in a recession, volatility in the financial market will increase. This will encourage investors to switch their investments to safer instruments to reduce the associated risks. In a situation like this, investors tend to choose an investment with fixed revenue like bonds or sukuk. This opinion is also supported by research conducted by Baur and Lucey (2009), Durand et al. (2009), Mustafa et al. (2015).

\subsection{Relationship of trade openness towards Islamic stock market development}

From the test conducted, it was found that trade openness does not have a significant influence towards Islamic stock market development in Indonesia and Malaysia. These research results are contradictory with previous studies done by El-Wassal (2016), Ho and Iyke (2017), in which their research results showed that trade openness has a positive effect towards stock market development.

Then it was revealed that trade openness does not have a significant influence towards sukuk market development and economic growth in Indonesia. However, in Malaysia, it was discovered that trade openness has a significant and positive influence towards sukuk market development and economic growth. When the export and import values of Malaysia experience an increase, it will increase the sukuk market development and economic growth in the country. These results are in line with previous research conducted by Said and Grassa (2013) in the Islamic financial industry, and studies by Bhattacharyay (2013), Braun and Raddatz (2005), Grossman and Helpman (1994), Rajan and Zingales (2003) in the conventional financial industry.

Trade openness which does not show a significant influence in Indonesia can be due to the small trade openness index in Indonesia (foreign trade ratio towards PDB). In 2016, the trade openness index of Indonesia was 37, while in the same year, the trade openness index of Malaysia reached 129 ("World Bank Indicators" 2018).

\section{Conclusions and policy implications}

The VECM estimation results convey that in Indonesia, Islamic stock market development has a positive influence towards sukuk market development, and sukuk market development has a positive influence towards Islamic stock market development. Meanwhile, in Malaysia it was found that there is a flight-to-quality phenomenon, where there is a reciprocal relationship between the stock market and sukuk market with a negative influence.

The economic growth variable has a significant and negative influence towards the Islamic stock market development variable, and the Islamic stock market has a significant and negative influence towards economic growth in Indonesia. Meanwhile, in Malaysia there was no significant influence found between variables. Next, in Indonesia, economic growth has a significant and negative influence towards sukuk development, and sukuk market development also has a negative influence towards economic growth. Then in Malaysia only economic growth shows a significant and negative influence towards sukuk market development. Trade openness was discovered to have a significant and positive influence towards sukuk market development and economic growth in Malaysia (Endogenous 
Growth Theory). Meanwhile, in Indonesia trade openness does not have a significant influence towards Islamic stock market development, sukuk market development, or economic growth.

The VECM Granger causality test estimation results found that in Indonesia, there is two-directional causality between Islamic stock market development and sukuk market development; there is two-directional causality between economic development and stock market development; and there is two-directional causality between sukuk market development and economic growth. Next, in Malaysia, it was discovered that there is two-directional causality between Islamic stock market development and sukuk market development; there is a one-directional relationship between economic growth and sukuk market development; and there is neutrality (no causality) between Islamic stock market development and economic growth.

These research results indicate that the policy decision makers should recognize the current differences in the relationship between the Islamic financial market and economic growth in an effort to sustain development. In building a portfolio in the Islamic financial market, investors also must pay attention to the influences between markets, keeping in mind that there are varying influences in different countries. Then the economic condition of a country can cause a shift in the Islamic stock market and sukuk market, so that investing can become an economic condition as a cornerstone in investment decision making, in order that risks can be reduced. Seeing that trade openness has a positive influence towards sukuk development and economic growth in Malaysia, the government needs to consider a policy to increase overseas trading, so that economic growth and sukuk market development can be achieved.

This study also suggests sukuk investor in Indonesia to aware about Islamic stock market condition in Indonesia, because it will affect the sukuk market in the same direction. Portfolio formation between sukuk and Islamic stocks in Indonesia will not produce a diversification benefit, but it will produce a diversification benefit in Malaysia because sukuk market and Islamic stock market have negative relationship.

For the limitations, this research only focused on two countries and only delved into the corporation sukuk market. Future research should try to add sample countries and expand research to sovereign/state sukuk markets.

\section{Funding}

This research received no specific grant from any funding agency in the public, commercial, or not-for-profit sectors.

\section{Author contributions}

Harjum Muharam and Resi Junita Anwar conceived the study and were responsible for the design and development of the data analysis. Harjum Muharam and Resi Junita Anwar were responsible for data collection and analysis. Harjum Muharam, Resi Junita Anwar and Robiyanto Robiyanto were responsible for data interpretation. Harjum Muharam, Resi Junita Anwar and Robiyanto Robiyanto wrote the first draft of the article.

\section{Disclosure statement}

Authors declare that there is no conflict of interest.

\section{References}

Ahmed AD, Mmolainyane KK (2014) Financial integration, capital market development and economic performance: Empirical evidence from Botswana. Economic Modelling 42: 1-14. https://doi.org/10.1016/j.econmod.2014.05.040

Alam N, Hassan MK, Haque MA (2013) Are Islamic bonds different from conventional bonds? International evidence from capital market tests. Borsa Istanbul Review 13 (3): 2229. https://doi.org/10.1016/j.bir.2013.10.006

Aloui C, Hammoudeh S, Hamida HB (2015) Co-movement between sharia stocks and sukuk in the GCC markets: A time-frequency analysis. Journal of International Financial Markets, Institutions and Money 34: 69-79. https://doi. org/10.1016/j.intfin.2014.11.003

Atje R, Jovanovic B (1993) Stock markets and development. European Economic Review 37 (2-3): 632-640. https://doi. org/10.1016/0014-2921(93)90053-D

Baele L, Bekaert G, Inghelbrecht K (2010) The determinants of stock and bond return comovements. Review of Financial Studies 23 (6): 2374-2428. https://doi.org/10.1093/rfs/hhq014

Bansal N, Connolly RA, Stivers C (2014) The stock-bond return relation, the term structure's slope, and asset-class risk dynamics. Journal of Financial and Quantitative Analysis 49 (03): 699-724. https://doi.org/10.1017/S0022109014000258

Baur DG, Lucey BM (2009) Flights and contagion - An empirical analysis of stock-bond correlations. Journal of Financial Stability 5 (4): 339-352. https://doi.org/10.1016/j.jfs.2008.08.001

Bhattacharyay BN (2013) Determinants of bond market development in Asia. Journal of Asian Economics 24: 124-137. https://doi.org/10.1016/j.asieco.2012.11.002

Bhide A (1993) The hidden costs of stock market liquidity. Journal of Financial Economics 34 (1): 31-51. https://doi. org/10.1016/0304-405X(93)90039-E

Bordo MD, Murshid AP (2001) Are financial crises becoming more contagious?: What is the historical evidence on contagion? In: CS and FKJ (Eds) International financial contagion. Boston, MA: Springer. https://doi.org/10.1007/978-1-47573314-3_14

Braun M, Raddatz C (2005) Trade liberalization and the politics of financial development. In: World Bank Policy Research Working Papers 3517. https://doi.org/10.1596/1813-9450-3517

Chiang TC, Li J, Yang S-Y (2014) Dynamic stock-bond return correlations and financial market uncertainty. Review of Quantitative Finance and Accounting 45 (1): 59-88. https:// doi.org/10.1007/s11156-013-0430-4 
Dickey DA, Fuller WA (1979) Distribution of the estimators for autoregressive time series with a unit root. Journal of the American Statistical Association 71 (366): 427-431. https:// doi.org/10.2307/2286348

Durand RB, Junker M, Szimayer A (2009) The flight-to-quality effect: a copula-based analysis. Accounting \& Finance 50 (2): 281-299. https://doi.org/10.1111/j.1467-629X.2009.00320.x

El-Wassal KA (2016) Understanding the growth in emerging stock markets. Journal of Emerging Market Finance 4 (3): 227-261. https://doi.org/10.1177/097265270500400302

Engle RF, Granger CWJ (1987) Co-Integration and error correction: Representation, estimation, and testing. Econometrica 55 (2): 251-276. https://doi.org/10.2307/1913236

Enisan AA, Olufisayo AO (2009) Stock market development and economic growth: Evidence from seven sub-Sahara African countries. Journal of Economics and Business 61 (2): 162-171. https://doi.org/10.1016/j.jeconbus.2008.05.001

Granger CWJ (1969) Investigating causal relations by econometric models and cross-spectral methods. Econometrica 37 (3): 424-438. https://doi.org/10.2307/1912791

Grossman GM, Helpman E (1994) Endogenous Innovation in the Theory of Growth. The Journal of Economic Perspectives 8 (1): 23-44. https://doi.org/10.1257/jep.8.1.23

Guler B, Ozlale U (2005) Is there a flight to quality due to inflation uncertainty? Physica A: Statistical Mechanics and its Applications 345 (3-4): 603-607. https://doi.org/10.1016/ S0378-4371(04)01060-X

Handriani E, Robiyanto R (2018) Investment opportunity and industrial growth in Indonesia. International Journal of Business and Society 19 (2): 295-312.

Ho S-Y, Iyke BN (2017) On the causal links between the stock market and the economy of Hong Kong. Contemporary Economics 11 (3): 343-362.

ICD (2017) Islamic Finance Development Indicator Report 2017. Thomson Reuters.

IFSB (2017) Islamic Financial Services Industry Report 2017. Kuala Lumpur, Malaysia: Islamic Financial Services Board.

Istiqomah (2012) Dinamika Interaksi antara Variabel Moneter dan Pasar Modal Syariah Terhadap Pertumbuhan Ekonomi Indonesia. Working Paper.

Johansen S, Juselius K (1990) Maximum likelihood estimation and inference on cointegration - with applications to the demand for money. Oxford Bulletin Economis and Statistics 52 (2): 169-210. https://doi.org/10.1111/j.1468-0084.1990. mp52002003.x

Levine R (1997) Financial development and economic growth: Views and agenda. Journal of Economic Literature 35 (2): 688-726.

Luintela KB, Khan M (1999) A quantitative reassessment of the finance-growth nexus: evidence from a multivariate VAR. Journal of Development Economics 60 (2): 381-405. https:// doi.org/10.1016/S0304-3878(99)00045-0

Marques LM, Fuinhas JA, Marques AC (2013) Does the stock market cause economic growth? Portuguese evidence of economic regime change. Economic Modelling 32: 316-324. https://doi.org/10.1016/j.econmod.2013.02.015
Mohamed MR (2018) Malaysian Bond \& Sukuk Market: An Overview. Paper presented at the Showcasing Asian Bond Markets: Opportunities And Risks, An ACRAA Conference In Cooperation With Asian Bankers Association, Manama, Bahrain. http://acraa.com/doc/5\%20Malaysia\%20Bond\%20 Market.pdf

Mohd NHH, Low S-W, Nor AHSM, Ghazali NA (2013) FDI and economic growth - does the quality of banking development matter? Gadjah Mada International Journal of Business 15 (3): 287-303. https://doi.org/10.22146/gamaijb.5472

Muharam H, Setyowati D (2017) Kausalitas Perkembangan Pasar Saham, Perkembangan Pasar Obligasi, Pertumbuhan Ekonomi, dan Investasi Langsung Asing. Working Paper.

Mustafa NNS, Samsudin S, Shahadan F, Yi AKJ (2015) Flight-toquality between stock and bond markets: pre and post global financial crisis. Procedia Economics and Finance 31: 846-855. https://doi.org/10.1016/S2212-5671(15)01178-8

Naifar N, Hammoudeh S, Al dohaiman MS (2016) Dependence structure between sukuk (Islamic bonds) and stock market conditions: An empirical analysis with Archimedean copulas. Journal of International Financial Markets, Institutions and Money 44: 148-165. https://doi.org/10.1016/j. intfin.2016.05.003

Newbery DMG, Stiglitz JE (1984) Pareto inferior trade. The Review of Economic Studies 51 (1): 1-12. https://doi. org/10.2307/2297701

Ngare E, Nyamongo EM, Misati RN (2014) Stock market development and economic growth in Africa. Journal of Economics and Business 74: 24-39. https://doi.org/10.1016/j. jeconbus.2014.03.002

Olweny TO, Kimani D (2011) Stock market performance and economic growth: Empirical evidence from Kenya using causality test approach Advances in Management \& Applied Economics 1 (3): 153-196.

Patoda R, Jain K (2012) Assimilation between Bond and Stock Market. Global Journal of Management and Business Research 12 (20).

Pradhan RP, Arvin MB, Hall JH, Bahmani S (2014) Causal nexus between economic growth, banking sector development, stock market development, and other macroeconomic variables: The case of ASEAN countries. Review of Financial Economics 23 (4): 155-173. https://doi.org/10.1016/j. rfe.2014.07.002

Pradhan RP, Zaki DB, Maradana RP, Dash S, Jayakumar M, Chatterjee D (2015) Bond market development and economic growth: The G-20 experience. Tékhne 13 (1): 51-65. https:// doi.org/10.1016/j.tekhne.2015.09.003

Rajan RG, Zingales L (2003) The great reversals: the politics of financial development in the twentieth century. Journal of Financial Economics 69 (1): 5-50. https://doi.org/10.1016/ S0304-405X(03)00125-9

Robinson J (1952) The generalization of the General Theory, in the Rate of interest and other essays. London: Macmillan.

Robiyanto R (2017) The Analysis of capital market integration in ASEAN Region by using the OGARCH approach. Jurnal Keuangan dan Perbankan 21 (2): 169-175. https://doi. org/10.26905/jkdp.v21i2.1138 
Robiyanto R (2018a) Gold VS Bond: What Is the safe haven for the Indonesian and Malaysian capital market? Gadjah Mada International Journal of Business 20 (3): 277-302. https://doi. org/10.22146/gamaijb.27775

Robiyanto R (2018b) Indonesian stock market's dynamic integration with Asian stock markets and world stock markets. Jurnal Pengurusan 52: 181-192.

Robiyanto R (2018c) Testing of the Gold's role as a safe haven and hedge for Sharia stocks in Indonesia. Al-Iqtishad: Jurnal Ilmu Ekonomi Syariah 10 (2): 255-266. https://doi.org/10.15408/ aiq.v10i2.6527

Robiyanto R, Ernayani R (2018) Capital market integration in some ASEAN countries revisited. Jurnal Manajemen 22 (2): 205-222. https://doi.org/10.24912/jm.v22i2.359

Robiyanto R, Wahyudi S, Pangestuti IRD (2017a) Testing commodities as safe haven and hedging instrument on ASEAN's five stock markets. Jurnal Ekonomi Kuantitatif Terapan 10 (2): 231-238. https://doi.org/10.24843/JEKT.2017.v10.i02.p11

Robiyanto R, Wahyudi S, Pangestuti IRD (2017b) The volatility-variability hypotheses testing and hedging effectiveness of precious metals for the Indonesian and Malaysian capital markets. Gadjah Mada International Journal of Business 19 (2): 167-192. https://doi.org/10.22146/gamaijb.26260

Romer PM (1990) Endogenous technological chan. Journal of Political Economy 98 (5): S71-S102. https://doi. org/10.1086/261725

Said A, Grassa R (2013) The determinants of Sukuk market development: Does macroeconomic factors influence the construction of certain structure of Sukuk? Journal of Applied Finance \& Banking 3 (5): 251-267.

Schumpeter JA (1912) The theory of economic development. Cambridge, MA: Harvard University Press.
Smaoui H, Nechi S (2017) Does sukuk market development spur economic growth? Research in International Business and Finance 41: 136-147. https://doi.org/10.1016/j.ribaf.2017.04.018

Suganda TR, Sumargo IK, Robiyanto R (2018) Superstitious behavior and stock returns: The case of Javanese traditional calendar. Kasetsart Journal of Social Sciences (Article in Press). https://doi.org/10.1016/j.kjss.2018.08.008

Svaleryd H, Vlachos J (2002) Markets for risk and openness to trade: how are they related? Journal of International Economics 57 (2): 369-395. https://doi.org/10.1016/S00221996(01)00153-2

Vazakidis A, Adamopoulos A (2009) Financial development and economic growth: An empirical analysis for Greece. American Journal of Applied Sciences 6 (7): 1410-1417. https://doi. org/10.3844/ajassp.2009.1410.1417

Wahyudi S, Nofendi D, Robiyanto R, Hersugondo H (2018) Factors affecting return on deposit (ROD) of sharia banks in Indonesia. Business: Theory and Practice 19: 166-176. https:// doi.org/10.3846/btp.2018.17

Wang YS, Chueh YL (2013) Dynamic transmission effects between the interest rate, the US dollar, and gold and crude oil prices. Economic Modelling 30: 792-798. https://doi. org/10.1016/j.econmod.2012.09.052

Wanyama DW (2017) Effect of stock market development on the growth of corporate bond market in Kenya. International Journal of Finance (IJF) 2 (2).

World Bank Indicators (2018) http://www.worldbank. org/?CID=ECR_GA_worldbank_EN_EXTP_AM2018\&gcl id=EAIaIQobChMIsJv2_6GL3gIVCK6WCh0HfgGVEAAY ASAAEgIHGvD_BwE

Yartey CA (2007) Well-developed financial intermediary sector promotes stock market development: Evidence from Africa. Journal of Emerging Market Finance 6 (3): 269-289. https:// doi.org/10.1177/097265270700600303 